\title{
Establishing Normal Ranges of Basal and ACTH-Stimulated Serum Free Cortisol in Children
}

\author{
Ori Eyal ${ }^{a, c}$ Rona Limor ${ }^{b} \quad$ Asaf Oren ${ }^{a, c}$ Anita Schachter-Davidov ${ }^{a, c}$ \\ Naftali Stern $^{b, c}$ Naomi Weintroba, \\ a Pediatric Endocrinology and Diabetes Unit, Dana-Dwek Children's Hospital and ' Institute of Endocrinology, \\ Metabolism and Hypertension, Tel Aviv Sourasky Medical Center, and 'Sackler Faculty of Medicine, Tel Aviv \\ University, Tel Aviv, Israel
}

\section{Key Words}

Free cortisol · Total cortisol · ACTH test · Normal values

\begin{abstract}
Background: Normative data have been established for stimulated serum total cortisol in children but not for serum free cortisol. Methods: Children who were referred for ACTH testing to rule out adrenal insufficiency were enrolled. Only children with normal response and normal androgen levels were included. Total cortisol was determined by a chemiluminescence method, and free cortisol was measured by the same method following equilibrium dialysis. Results: The study group consisted of 85 subjects ( 28 male; 57 female) with a median age of 8.5 years (range $0.6-17.7$ ). The mean basal and peak total cortisol levels were $11.5 \pm 5.7$ and 32.9 $\pm 6.2 \mu \mathrm{g} / \mathrm{dl}$, respectively. The mean basal and peak free cortisol levels were $0.4 \pm 0.3$ and $1.8 \pm 0.6 \mu \mathrm{g} / \mathrm{dl}$, respectively. There was a negative correlation between peak total cortisol and age but not between peak free cortisol and age. The 3rd and 97th percentile values for peak free cortisol were 0.94 $\mu \mathrm{g} / \mathrm{dl}(26 \mathrm{nmol} / \mathrm{l})$ and $2.97 \mu \mathrm{g} / \mathrm{dl}(82 \mathrm{nmol} / \mathrm{l})$, respectively. Conclusions: Measurement of free cortisol has the advantage of being independent of cortisol-binding globulin lev-
\end{abstract}

\section{KARGER}

(c) 2016 S. Karger AG, Basel

E-Mail karger@karger.com

www.karger.com/hrp els. This study provides reference ranges for stimulated free cortisol in children, with a cutoff value of $0.9 \mu \mathrm{g} / \mathrm{dl}(25 \mathrm{nmol} / \mathrm{l})$ as a normal response to a standard ACTH test.

(c) 2016 S. Karger AG, Basel

\section{Introduction}

More than $90 \%$ of the serum cortisol is protein bound. Between 80 and $90 \%$ of the circulating cortisol is bound to cortisol-binding globulin (CBG), $10-15 \%$ is bound to albumin and $5-10 \%$ circulates as free and active hormone. Changes in binding proteins can alter measured serum total cortisol without influencing serum free cortisol concentrations [1-3]. Estrogen, oral contraception, pregnancy, and liver disease increase CBG, while malnutrition, nephrotic syndrome, and dilutional states, such as heart failure, decrease both albumin and CBG and may cause subnormal ACTH-stimulated total cortisol levels, leading to the erroneous diagnosis of adrenal insufficiency and unnecessary glucocorticoid therapy [4]. Although total cortisol generally correlates well with the free fraction, there are clinical conditions, such as major surgery, severe illness, or acute phase of septic shock and stress, in

Dr. Ori Eyal

Pediatric Endocrinology and Diabetes Unit, Dana-Dwek Children's Hospital, Tel Aviv Sourasky Medical Center

6 Weizman Street, Tel Aviv 6423906 (Israel)

E-Mail oriey@tlvmc.gov.il 
which large changes in CBG and albumin concentration take place, thus raising a real need for the measurement of free cortisol concentration [4-8]. Hypoalbuminemia and alterations in the binding of cortisol may lead to subnormal total cortisol responses to ACTH, while the free cortisol response can remain entirely normal in subjects with severe acute illness [9]. Other examples in which free cortisol measurement becomes particularly important are the rare cases of inactive corticosteroid-binding globulin, such as CBG-Lyon [10] or congenital CBG deficiency $[11,12]$. The current consensus is that the free rather than the protein-bound fraction of cortisol is responsible for its physiological function [4].

It is therefore desirable to establish reference ranges for free cortisol in order to prevent misdiagnosis and unnecessary treatment with corticosteroids. While normal free cortisol levels have been established for adults [13], there are no comparable data for children. In this study, we aimed to assess normal values for free cortisol levels in relation to total cortisol, age, and the pubertal stage in children who had been referred for evaluation of their hypothalamus-pituitary-adrenal (HPA) axis in order to rule out adrenal insufficiency/enzymatic defect. The study group consisted of children in whom altered adrenal function was suspected but cortisol deficiency was not likely and ultimately excluded.

\section{Materials and Methods}

\section{Subjects}

Children (age $0.5-18$ years) who were referred for ACTH testing at our unit in order to rule out adrenal insufficiency or adrenal enzymatic defect were invited to participate in the study. All tests were performed between 8 and 9 a.m. in order to measure morning basal cortisol. The reasons for referral were: precocious pubarche $(n=42)$, advanced puberty $(n=20)$, adrenarche before gonadarche $(n=9)$, hirsutism $(n=7)$, acne $(n=3)$, advanced bone age $(n=2)$, and parental nonclassical 21 hydroxylase deficiency $(n=2)$. Puberty was assessed clinically according to the criteria of Marshall and Tanner $[14,15]$ by an experienced pediatric endocrinologist. In this study, we defined the Tanner stage by breast stage in girls and testicular volume in boys $[14,15]$. Only children with normal ACTH-stimulated total cortisol and 17OHP findings and normal testosterone and androstenedione levels were included. The cutoff value was set at $>20$ $\mu \mathrm{g} / \mathrm{dl}(>550 \mathrm{nmol} / \mathrm{l})$ for total cortisol $[16,17]$ and at $<330 \mu \mathrm{g} / \mathrm{dl}(<10$ $\mathrm{nmol} / \mathrm{l}$ ) for 17OHP [18]. Testosterone and androstenedione levels were measured and matched for age, sex, and pubertal stage [19].

\section{Methods}

Synachten (Sigma-Tau, Rome, Italy) was injected intravenously at a dose of $250 \mu \mathrm{g} / \mathrm{m}^{2}$ (up to a maximal dose of $250 \mu \mathrm{g}$ ). Blood was drawn for the evaluation of cortisol and free cortisol at baseline and at 30 and $60 \mathrm{~min}$ after the injection. Total cortisol was measured by
Table 1. Basal and ACTH-stimulated serum total and free cortisol levels in 85 subjects aged between 0.6 and 17.7 years, showing a higher fraction of peak serum free cortisol compared with basal serum free cortisol

\begin{tabular}{|c|c|c|c|}
\hline & $\begin{array}{l}\text { Total cortisol, } \\
\mu \mathrm{g} / \mathrm{dl}\end{array}$ & $\begin{array}{l}\text { Free cortisol, } \\
\mu \mathrm{g} / \mathrm{dl}\end{array}$ & $\begin{array}{l}\text { Fraction of free } \\
\text { cortisol, } \%\end{array}$ \\
\hline \multicolumn{4}{|l|}{ Baseline } \\
\hline Mean \pm SD & $11.53 \pm 5.74$ & $0.42 \pm 0.30$ & $3.95 \pm 1.73$ \\
\hline $95 \% \mathrm{CI}$ & $10.29-12.77$ & $0.36-0.49$ & $3.57-4.33$ \\
\hline \multicolumn{4}{|l|}{ Peak } \\
\hline Mean \pm SD & $32.95 \pm 6.22$ & $1.82 \pm 0.63$ & $6.69 \pm 2.06$ \\
\hline $95 \%$ CI & $31.61-34.29$ & $1.68-1.96$ & $6.23-7.13$ \\
\hline \multicolumn{4}{|l|}{$\%$ Increase } \\
\hline Mean \pm SD & $258 \pm 180$ & $504 \pm 426$ & $87 \pm 70$ \\
\hline $95 \%$ CI & $218-297$ & $410-597$ & $72-102$ \\
\hline
\end{tabular}

$\mathrm{p}<0.001$ for $\%$ increase between free cortisol and total cortisol. To convert total and free cortisol $\mu \mathrm{g} / \mathrm{dl}$ to $\mathrm{nmol} / \mathrm{l}$, multiply by 27.6 .

electrochemiluminescence (Cobas A 411; Roche, Indianapolis, Ind., USA). The intra- and interassay coefficients of variation were 1.4 and $1.6 \%$, respectively. Free cortisol was determined by equilibrium dialysis. The equilibrium dialysis cells Slide-A-Lyzer mini dialysis units 7,000 molecular weight cutoff used (Pierce, Rockford, Ill., USA) were disposable dialysis cups made of polypropylene and low-binding regenerated cellulose membranes. After $15 \mathrm{~min}$ of soaking in 1 liter of water for glycerol removal, the dialysis unit was placed in a microtube filled with $1 \mathrm{ml}$ dialysate buffer. The human serum for dialysis was placed in the unit cell $(500 \mu \mathrm{l})$. Each liter of dialysate buffer contained sodium chloride ( $5.265 \mathrm{~g}), 60 \%$ syrup of DL-lactic acid as the sodium salt $(1 \mathrm{ml}), \mathrm{L}$-glutamic acid as the monosodium salt $(561 \mathrm{mg})$, potassium chloride $(224 \mathrm{mg})$, monopotassium phosphate $(180 \mathrm{mg})$, calcium chloride dihydrate (275 $\mathrm{mg}$ ), magnesium sulphate heptahydrate (246 mg), urea (300 mg), HEPES sodium salt (5.891 g), HEPES acid (7.19 g), penicillin (100,000 USP units), streptomycin (100 mg), amphotericin B (0.25 $\mathrm{mg})$, gentamicin $(100 \mathrm{mg})$, sodium azide $(520 \mathrm{mg})$, gelatin $(500$ $\mathrm{mg})$, and rabbit IgG (200 mg). The chemicals were obtained from Sigma Chemical Co., Saint Louis, Mo., USA. The equilibrium dialysis was performed in a water bath at $37^{\circ} \mathrm{C}$ for $24 \mathrm{~h}$ with continuous agitation. The cortisol was then measured in the dialyzed serum by electrochemiluminescence. The intra- and interassay coefficients of variation of the assay were 8 and $12 \%$, respectively [13].

Statistical analysis was done using the BMDP program [20]. Descriptive statistics are given as mean (SD) for continuous variables and as frequency for categorical variables. Discrete variables were compared using Pearson's $\chi^{2}$ test or Fisher's exact test as appropriate. Comparisons between continuous variables were performed using one-way ANOVA. We tested for equal variances using Levene's test. If Levene's test was significant, we used the equality of means test Welch or Brown-Forsythe. Pearson's correlation was applied to detect correlations between different parameters. A $p$ value of $\leq 0.05$ was considered significant. 
Table 2. Basal and stimulated serum free cortisol by gender and Tanner breast stage in girls and genital stage in boys

\begin{tabular}{|c|c|c|c|c|c|c|}
\hline & \multicolumn{3}{|l|}{ Girls } & \multicolumn{3}{|l|}{ Boys } \\
\hline & B1 & $\mathrm{B} 2-3$ & $\mathrm{~B} 4-5$ & G1 & $\mathrm{G} 2-3$ & $\mathrm{G} 4-5$ \\
\hline Number of children & 30 & 10 & 12 & 16 & 6 & 3 \\
\hline Basal free cortisol $^{\mathrm{a}}$ & $0.40 \pm 0.26$ & $0.47 \pm 0.20$ & $0.52 \pm 0.43$ & $0.27 \pm 0.22$ & $0.52 \pm 0.32$ & $0.64 \pm 0.66$ \\
\hline$\%$ free cortisol at baseline ${ }^{b}$ & $3.4 \pm 1.32$ & $4.4 \pm 1.74$ & $4.6 \pm 1.97$ & $3.2 \pm 1.51$ & $5.2 \pm 2.18$ & $4.7 \pm 0.93$ \\
\hline Peak free cortisol ${ }^{c}$ & $1.88 \pm 0.66$ & $1.79 \pm 0.56$ & $1.87 \pm 0.58$ & $1.65 \pm 0.45$ & $1.87 \pm 1.17$ & $2.08 \pm 0.74$ \\
\hline$\%$ free cortisol at peak ${ }^{\mathrm{d}}$ & $6.3 \pm 1.98$ & $6.5 \pm 1.35$ & $7.6 \pm 2.39$ & $6.5 \pm 1.95$ & $7.1 \pm 3.20$ & $8.4 \pm 1.31$ \\
\hline
\end{tabular}

Values are expressed as mean $\pm \mathrm{SD}$, unless otherwise indicated. There was a significant difference in basal serum free cortisol levels and the fraction of serum free cortisol at baseline between the three Tanner stage groups in both sexes, but this difference was not found for peak serum free cortisol and the fraction of serum free cortisol at peak. No difference was found between the sexes. Free cortisol is given in $\mu \mathrm{g} / \mathrm{dl}$. To convert to nmol/l, multiply by 27.6 . B1-5, G1-5 $=$ Tanner stages. ${ }^{\mathrm{a}} \mathrm{p}=0.86$ for gender, $\mathrm{p}=0.04$ for Tanner stage, $\mathrm{p}=0.4$ for interaction between gender and Tanner stage. ${ }^{\mathrm{b}} \mathrm{p}=0.5$ for gender, $\mathrm{p}=0.003$ for Tanner stage, $\mathrm{p}=0.6$ for interaction between gender and Tanner stage. ${ }^{c} \mathrm{p}=0.94$ for gender, $\mathrm{p}=0.66$ for Tanner stage, $\mathrm{p}=0.55$ for interaction between gender and Tanner stage. ${ }_{\mathrm{d}} \mathrm{p}=0.39$ for gender, $\mathrm{p}=0.09$ for Tanner stage, $\mathrm{p}=0.9$ for interaction between gender and Tanner stage.

Statement of Ethics

Written informed consent was obtained from the parents or guardians on behalf of their child. The study was approved by the medical Ethics Committee of Tel Aviv Sourasky Medical Center.

\section{Results}

The study group consisted of 85 subjects ( 57 girls and 28 boys) whose median age was 8.5 years (range $0.6-$ 17.7). Forty-six of them were prepubertal, 16 were Tanner breast/genital stages 2 or 3 , and 15 were stages 4 or 5 . Pubertal stage data were missing for 8 patients. Basal and peak total and free cortisol levels and free cortisol fractions are given in table 1.

\section{Basal Total and Free Cortisol Levels}

The $3 \mathrm{rd}$ percentile for basal total cortisol was $3.5 \mu \mathrm{g} / \mathrm{dl}$ $(96 \mathrm{nmol} / \mathrm{l})$, and the $97 \mathrm{th}$ percentile was $25.6 \mu \mathrm{g} / \mathrm{dl}(706$ $\mathrm{nmol} / \mathrm{l})$. The $3 \mathrm{rd}$ percentile for basal free cortisol was 0.07 $\mu \mathrm{g} / \mathrm{dl}(2 \mathrm{nmol} / \mathrm{l})$, and the $97 \mathrm{th}$ percentile was $1.2 \mu \mathrm{g} / \mathrm{dl}$ (33 $\mathrm{nmol} / \mathrm{l})$.

Baseline and peak total cortisol and free cortisol were positively correlated $(\mathrm{r}=0.8, \mathrm{p}<0.001$ and $\mathrm{r}=0.5, \mathrm{p}<$ 0.001 , respectively). There was a negative correlation between the peak total cortisol level and age $(\mathrm{r}=-0.3, \mathrm{p}=$ 0.001 ) but not between peak free cortisol and age.

\section{Total and Free Cortisol Levels in Relation to Age Groups}

The subjects were divided into three age groups $(<5$ years, $5-10$ years, and $>10$ years). There was no difference in the mean basal total cortisol levels among the three age groups, but there was a significant difference in the mean peak total cortisol levels $[36.2 \pm 5.63 \mu \mathrm{g} / \mathrm{dl}(999 \pm 155$ $\mathrm{nmol} / \mathrm{l}), 33.25 \pm 6.67 \mu \mathrm{g} / \mathrm{dl}(917 \pm 184 \mathrm{nmol} / \mathrm{l})$, and 30.21 $\pm 4.5 \mu \mathrm{g} / \mathrm{dl}(833 \pm 124 \mathrm{nmol} / \mathrm{l})$, ANOVA $\mathrm{p}<0.01]$. The mean free cortisol baseline level was similar for the three age groups $[0.41 \pm 0.28 \mu \mathrm{g} / \mathrm{dl}(11 \pm 8 \mathrm{nmol} / \mathrm{l}), 0.41 \pm 0.27$ $\mu \mathrm{g} / \mathrm{dl}(11 \pm 7 \mathrm{nmol} / \mathrm{l})$, and $0.45 \pm 0.37 \mu \mathrm{g} / \mathrm{dl}(12 \pm 10$ $\mathrm{nmol} / \mathrm{l})]$. However, there was a trend for higher peak free cortisol values in children $<5$ years of age [ $2.21 \pm 0.62 \mu \mathrm{g} /$ $\mathrm{dl}(61 \pm 17 \mathrm{nmol} / \mathrm{l}), 1.70 \pm 0.52 \mu \mathrm{g} / \mathrm{dl}(47 \pm 14 \mathrm{nmol} / \mathrm{l})$, and $1.85 \pm 0.78 \mu \mathrm{g} / \mathrm{dl}(51 \pm 22 \mathrm{nmol} / \mathrm{l})$, ANOVA p $=0.06]$.

\section{Stimulated Total and Free Cortisol Level}

The 3rd percentile for peak total cortisol was $24.3 \mu \mathrm{g} /$ $\mathrm{dl}(670 \mathrm{nmol} / \mathrm{l})$, and the $97 \mathrm{th}$ percentile was $44.4 \mu \mathrm{g} / \mathrm{dl}$ $(1225 \mathrm{nmol} / \mathrm{l})$. The $3 \mathrm{rd}$ percentile value for the mean peak free cortisol level was $0.94 \mu \mathrm{g} / \mathrm{dl}(26 \mathrm{nmol} / \mathrm{l})$, and the $97 \mathrm{th}$ percentile was $2.97 \mu \mathrm{g} / \mathrm{dl}(82 \mathrm{nmol} / \mathrm{l})$. Based on these values, we propose a cutoff value of $0.9 \mu \mathrm{g} / \mathrm{dl}(25 \mathrm{nmol} / \mathrm{l})$ as the normal response to a standard ACTH test.

\section{Total and Free Cortisol Levels in Relation to Gender and Pubertal Stage}

There were no significant gender differences in total cortisol and free cortisol levels even when the pubertal stage was taken into account. There was a significant difference in basal free cortisol levels between the three pubertal stage groups in both sexes (table 2). This difference was not found for the basal and peak total cortisol levels and the peak free cortisol levels (table 2). There was a pos-
96

Horm Res Paediatr 2016;86:94-99 DOI: $10.1159 / 000447946$
Eyal/Limor/Oren/Schachter-Davidov/ Stern/Weintrob 
itive correlation between basal free cortisol values and the pubertal stage $(r=0.25, p=0.03)$ but none was found between basal total cortisol and the pubertal stage. There was a negative correlation between peak total cortisol and age $(\mathrm{r}=-0.345, \mathrm{p}=0.001)$, as well as a positive correlation between the fraction of free cortisol at baseline and at peak and the pubertal stage $(\mathrm{r}=0.312, \mathrm{p}=0.006$ and $\mathrm{r}=$ $0.247, p=0.03$, respectively). No correlation was found between basal and stimulated total and free cortisol levels and body mass index standard deviation score.

\section{Discussion}

Alterations in CBG and albumin concentrations might cause misinterpretation of dynamic tests of the HPA axis due to their influence on total cortisol levels. This, in turn, can lead to an erroneous diagnosis of adrenal insufficiency and unnecessary glucocorticoid therapy. Therefore, assessment of the free fraction of circulating cortisol has been attempted, using indirectly calculated free cortisol or directly measured free cortisol. The free cortisol index, defined as serum total cortisol divided by the CBG level is a reliable measure of serum free cortisol [21]. However, it ignores both potential alternations in CBG-binding properties and the influence of albumin on the actual free cortisol fraction. The latter difficulty has been addressed by Dorin et al. [22] who showed that the measurement of serum albumin as well as that of CBG followed by a modified equation better approximates free cortisol as determined directly through ultrafiltration. Based on the results of this study, we propose normal values for basal and post-ACTH stimulation levels of free cortisol in children and adolescents. We demonstrated that the relative increase in free cortisol as a result of ACTH administration was significantly higher than the relative increase in total cortisol. This finding had not been demonstrated after a low-dose ACTH stimulation test in adults [13]. This difference might be explained by CBG saturation having been reached after a high-dose ACTH stimulation test. Specifically, CBG can bind up to $25 \mu \mathrm{g} / \mathrm{dl}$ of the circulating cortisol. As CBG becomes saturated, a larger proportion of circulating cortisol will be albumin bound and unbound [4]. The 6-fold increase in the free cortisol level during a standard ACTH test that was documented for our pediatric group is similar to the 7 - to 10 -fold increase in free cortisol concentration previously reported in a random sample taken from critical ill adult patients [9].

As expected in healthy subjects, there was a highly significant correlation between the total cortisol and free cortisol levels. Interestingly, there was a negative correlation between peak total cortisol and age but not for peak free cortisol. This finding for total cortisol was reported earlier by Lashansky et al. [19]. The reason for this is probably that CBG levels decrease with age [23]. Of note, the basal free cortisol and the basal and peak fraction of free cortisol increased with pubertal stage in both sexes, but no comparable increase was observed for total cortisol levels. These findings are compatible with the results on salivary cortisol reported by Kiess et al. [24]. Those authors found that salivary cortisol concentrations correlate significantly with pubertal stage. The increase in free cortisol levels with pubertal stages might reflect a higher overall activity of the adrenal gland during puberty [24]. Unlike Kiess et al. [24], however, we did not find any positive correlations between free cortisol levels with BMI SDS and age.

Eighty-one (95\%) of our study patients had baseline free cortisol levels of $0.07-1.2 \mu \mathrm{g} / \mathrm{dl}(0.2-3.3 \mathrm{nmol} / \mathrm{l})$ and peak levels of $0.94-2.97 \mu \mathrm{g} / \mathrm{dl}(2.6-8.3 \mathrm{nmol} / \mathrm{l})$. Based on these values, we propose a cutoff value of $0.9 \mu \mathrm{g} / \mathrm{dl}(2.5$ $\mathrm{nmol} / \mathrm{l}$ ) as normal response to a standard ACTH test. This cutoff point is the same as that found for adult subjects following low-dose ACTH testing [13] standard dose ACTH testing [25].

We used the standard ACTH test to assess the free cortisol response in children and adolescents. We have previously shown that the standard ACTH test is equivalent to a low-dose ACTH test and that it is highly correlated to insulin-induced hypoglycemia (the gold standard test) in detecting HPA sufficiency and insufficiency in children with either multiple pituitary hormone deficiency or isolated growth hormone deficiency [26]. In addition, a lowdose $(1 \mu \mathrm{g})$ ACTH test might show a high rate of abnormal responses due to technical problems [27]. There is no consensus regarding the cutoff value for total cortisol response to ACTH. Lindholm [17] proposed a cutoff of 18 or $20 \mu \mathrm{g} / \mathrm{dl}$ ( 500 or $550 \mathrm{nmol} / \mathrm{l}$, respectively). We had previously shown [26] that the cortisol response to standard ACTH stimulation test for children was $>22 \mu \mathrm{g} / \mathrm{dl}(>597$ $\mathrm{nmol} / \mathrm{l})$. Since all of our subjects had peak levels $>23 \mu \mathrm{g} /$ $\mathrm{dl}(>636 \mathrm{nmol} / \mathrm{l})$, selecting a lower value as the threshold used would not have changed the results.

Our study has several limitations: first, the carrier rate of mild CYP21A2 mutation is relatively high among Ashkenazi Jews (1:10 in Israel) [28]. We did not carry out a molecular analysis of the gene in our study group. However, by including only those participants with a peak $17 \mathrm{OHP}$ response to ACTH below $10 \mathrm{nmol} / \mathrm{l}$, we ensured that the vast majority of the patients were noncarriers [29, 
30]. In addition, since our study population was of a mixed origin, the rate of carriers was even lower than 1 : 10 [28]. Secondly, current assays for determining free cortisol concentrations are difficult to perform, timeconsuming, and labor-intensive. It is likely that rapid assays for measurements of free cortisol will become available in the near future, just as serum-free T4 assays became widely available for clinical use more than a decade ago [4]. Thirdly, since all tests were done in an outpatient setting, the baseline levels of cortisol and of free cortisol were obtained between 8 and 9 a.m., which could be after the circadian peak of cortisol. However, the time of the day does not have any impact on the ACTH-stimulated total and free cortisol levels [31], and they are the main outcome of this study. Lastly, although the study group was selected from all children who were referred for evaluation of adrenal function due to suspected adrenal dysfunction, only those with normal test results were included in the study.
In summary, we present normal reference values for free cortisol levels at baseline and after ACTH administration in healthy children and adolescents. These values will be helpful in evaluating adrenal reserve in pediatric subjects with conditions that affect total cortisol levels, such as in CBG deficiency, hypoproteinemia, dilutional states, or increased estrogen levels.

\section{Acknowledgements}

We thank P. Lilos for the statistical analysis and E. Eshkol for professional English editing.

\section{Disclosure Statement}

The authors declare that there are no conflicts of interest associated with this paper.

\section{References}

1 Dhillo WS, Kong WM, Le Roux CW, Alaghband-Zadeh J, Jones J, Carter G, Mendoza N, Meeran K, O’Shea D: Cortisol-binding globulin is important in the interpretation of dynamic tests of the hypothalamic-pituitary-adrenal axis. Eur J Endocrinol 2002;146:231235.

2 Smith JB, Nolan G, Jubiz W: The relationship between unbound and total cortisol: its usefulness in detecting CBG abnormalities. Clin Chim Acta 1980;108:435-445.

-3 Brien TG: Human corticosteroids binding globulin. Clin Endocrinol (Oxf) 1981;14:183212.

4 Arafah BM: Hypothalamic pituitary adrenal function during critical illness: limitation of current assessment methods. J Clin Endocrinol Metab 2006;91:3725-3745.

5 Mohler JL, Michael KA, Freedmann AM, Griffen WO, McRoberts JW: The serum and urinary cortisol response to operative trauma. Surg Gynecol Obstet 1985;161:445-449.

-6 LeRoux CW, Chapman GA, Kong WM, Dhillo WS, Jones J, Alaghband-Zadeh J: Free cortisol index is better than serum cortisol in determining hypothalamic-pituitary-adrenal status in patients undergoing surgery. J Clin Endocrinol Metab 2003;88:2045-2048.

7 Crist-Crain M, Jutla S, Widmer I, Couppis O, Konig C, Pargger H, Puder J, Edwards R, Muller B, Grossman AB: Measurement of serum free cortisol shows discordant responsivity to stress and dynamic evaluation. Clin Endocrinol Metab 2007;92:1729-1735.
8 Ho JT, Al-Musalhi H, Chapman MJ, Quach T, Thomas PD, Bagely CJ, Lewis JG, Torpy DJ: Septic shock and sepsis: a comparison of total and free plasma cortisol levels. J Clin Endocrinol Metab 2006;91:105-114.

-9 Hamrahian AH, Oseni TS, Arafah BM: Measurements of serum free cortisol in critically ill patients. N Engl J Med 2004;350:16291638.

10 Emptoz-Bonneton A, Cousin P, Seguchi K, Avvakumov GV, Bully C, Hammond GL, Pugeat M: Novel human corticosteroid-binding globulin variant with low cortisol-binding affinity. J Clin Endocrinol 2000;85:361-367.

11 Lewis JG, Bagley CJ, Elder PA, Bachmann A, Torpy DJ: Plasma free cortisol fraction reflects levels of functioning corticosteroidbinding globulin. Clin Chim Acta 2005;359: 189-194.

12 Simard M, Hill LA, Lewis JG, Hammond GL: Naturally occurring mutations of human corticosteroids-binding globulin. J Clin Endocrinol Metab 2015;100:E129-E139.

13 Limor R, Tordjman K, Marcus Y, Greenman Y, Osher E, Sofer Y, Stern N: Serum free cortisol as an ancillary tool in the interpretation of the low-dose 1- $\mu$ g ACTH test. Clin Endocrinol (Oxf) 2011;75:294-300.

14 Marshall WA, Tanner JM: Variation in the pattern of pubertal changes in girls. Arch Dis Child 1969;44:291-303.

15 Marshall WA, Tanner JM: Variation in the pattern of pubertal changes in boys. Arch Dis Child 1970;45:13-23.
16 Grinspoon SK, Biller BM: Laboratory assessment of adrenal insufficiency. J Clin Endocrinol Metab 1994;79:923-931.

17 Lindholm J: Problems in interpretation of the short ACTH test: an update and historical notes. Exp Clin Endocrinol Diabetes 2015; 123:441-445.

18 Witchel SF, Lee PA: Identification of heterozygotic carriers of 21-hydroxylase deficiency: sensitivity of ACTH stimulation tests. Am J Med Genet 1998;76:337-342.

19 Lashansky G, Saenger P, Fishman K, Gautier T, Mayes D, Berg G, Di Martino-Nardi J, Reiter E: Normative data for adrenal steroidogenesis in a healthy pediatric population: ageand sex-related changes after adrenocorticotropin stimulation. J Clin Endocrinol Metab 1991;73:674-686.

20 Dixon WJ (ed): BMDP Statistical Software. Los Angeles, University of California Press, 1993.

21 Le Roux CW, Sivakumaran S, Alaghband-Zadeh J, Dhillo W, Kong WM, Wheeler MJ: Free cortisol index as a surrogate marker for serum free cortisol. Ann Clin Biochem 2002;39:406408.

22 Dorin RI, Pai HK, Ho JT, Lewis JG, Torpy DJ, Urban FK, Qualls CR: Validation of a simple method of estimating plasma free cortisol: role of cortisol binding to albumin. Clin Biochem 2009;42:64-71. 
23 Fernandez-Real JM, Pugeat M, Grasa M, Broch M, Vendrell J, Brun J, Ricart W: Serum corticosteroid-binding globulin concentration and insulin resistance syndrome: a population study. J Clin Endocrinol Metab 2002; 87:4686-4690.

-24 Kiess W, Meidert A, Dressendörfer A, Schriever K, Kessler U, König A, Schwarz HP, Strasburger CJ: Salivary cortisol levels throughout childhood and adolescence: relation with age, pubertal stage, and weight. Pediatr Res 1995; 37:502-506.

25 Rauschecker M, Abraham SB, Abel BS, Wesley R, Saverino E, Trivedi A, Heller T, Nieman LK: Cosyntropin-stimulated serum free cortisol in healthy, adrenally insufficient, and mildly cirrhotic populations. J Clin Endocrinol Metab 2016;101:1075-1081.
26 Weintrob N, Sprecher E, Josefsberg Z, Weininger C, Aurbach-Klipper Y, Lazard D, Karp M, Pertzelan A: Standard and low-dose short adrenocorticotropin test compared with insulin-induced hypoglycemia for assessment of the hypothalamic-pituitary-adrenal axis in children with idiopathic multiple pituitary hormone deficiencies. J Clin Endocrinol Metab1998;83:88-92.

27 Wade M, Baid S, Calis K, Raff H, Sinaii N, Neiman L: Technical details influence the diagnostic accuracy of the $1 \mu \mathrm{g}$ ACTH stimulation test. Eur J Endocrinol 2010;162:109-113.

28 Israel S, Weinrib L, Weintrob N, Miller K, Brautbar C: Distribution of the V281L mutation of the CYP21 gene in Israeli congenital adrenal hyperplasia patients and its association with HLA-B14. Pediatr Endocrinol Rev 2006;3(suppl 3):447-450.
29 Napolitano E, Manieri C, Restivo F, Composto E, Lanfranco F, Repici M, Pasini B, Einaudi $S$, Menegatti E: Correlation between genotype and hormonal levels in heterozygous mutation carriers and non-carriers of 21-hydroxylase deficiency. J Endocrinol Invest 2011;34: 498-501.

30 Knochenhauer ES, Cortet-Rudelli C, Cunnigham RD, Conway-Myers BA, Dewailly D, Azziz R: Carriers of 21-hydroxylase deficiency are not at increased risk for hyperandrogenism. J Clin Endocrinol Metab 1997;82: 479-485.

31 Dickstein G, Shechner C, Nicholson WE, Rosner I, Shen-Orr Z, Adawi F, Lahav M: Adrenocorticotropin stimulation test: effect of basal cortisol level, time of day, and suggested new sensitive low dose test. J Clin Endocrinol Metab 1991;72:773-778. 